\title{
PENGARUH METODE PEMBELAJARAN COPERATIVE SCRIPT DAN KEMAMPUAN BERPIKIR HISTORIS TERHADAP HASIL BELAJAR SEJARAH SMA NEGERI 2 KOTO XI TARUSAN KABUPATEN PESISIR SELATAN PROVINSI SUMATERA BARAT
}

\author{
Ibnu Habib Alwahid ${ }^{1}$, Sarkadi $^{2}$, Umasih $^{3}$ \\ ${ }^{1,2,3}$ Pendidikan Sejarah Pasca Sarjana Universitas Negeri Jakarta \\ ibnuhabib090293@gmail.com
}

\begin{abstract}
Abstrak
Penelitian ini bertujuan untuk mengetahui dan mendapatan data yang empiris pengaruh metode pembelajaran cooperative script dan kemampuan berpikir historis terhadap hasil belajar SMA Negeri 2 Koto XI Tarusan Kabupaten Pesisir Selatan Pada Tahun Pelajaran 2017/2018. Penelitian ini berlangsung dari bulan februari 2018 sampai Maret 2018. Metode yang digunakan dalam penelitian ini adalah metode eksperimen dengan desain treatment by level $2 \times 2$. Dalam penelitian ini instrumen yang digunakan adalah untuk kemampuan berpikir historis dan hasil belajar adalah bebrbentuk tes pilihan ganda. Hasil penelitian ini menunjukkan bahwa: 1) hasil belajar sejarah siswa yang mengikuti metode pembelajaran cooperative script lebih tinggi dari siswa yang mengikuti metode pembelajaran konvensional, 2) terrdapat pengaruh interaksi antara metode pembelajaran dengan kemampuan berpikir historis terhadap hasil belajar siswa, 3) hasil belajar sejarah siswa yang diberikan metode pembelajaran cooperative script dengan memiliki kemampuan berpikir historis tinggi lebih tinggi dari siswa yang diberikan metode pembelajaran konvensional dengan memiliki kemampuan berpikir historis tinggi.4) hasil belajar sejarah siswa yang diberikan metode pembelajaran cooperative script dengan memiliki kemampuan berpikir historis rendah lebih rendah dari siswa yang diberikan metode pembelajaran konvensional dengan memiliki kemampuan berpikir historis rendah.
\end{abstract}

Kata Kunci : Hasil belajar sejarah, Metode pembelajaran cooperative script, Kemampuan berpikir historis

\section{Abstract}

This study aims to find and obtain empirical data the influence of cooperative script learning methods and the ability to think historically on the outcomes of SMA Negeri 2 Koto XI Tarusan Pesisir Selatan Regency in the Lesson Year 2017/2018. This research took place from February 2018 to March 2018. The method used in this research is the experimental method with design treatment by level $2 \times 2$. In this study the instruments used are for the ability of historical thinking and learning outcomes are bebrbentuk multiple choice test. The results of this study indicate that: 1) the result of learning history of students who follow cooperative script learning method is higher than students who follow the conventional learning method, 2) terrdapat interaction effect between learning methods with the ability to think historically on student learning outcomes, 3) students who are given cooperative script learning method with higher historical thinking ability than students given conventional learning method with high historical thinking ability. 4) the result of student history learning given cooperative script learning method with having low historical thinking ability lower than students are given conventional learning methods with low historical thinking ability.

Keywords: Historical learning result, cooperative script learning method, historical thinking ability 


\section{PENDAHULUAN}

Pembelajaran merupakan kegiatan untuk menghantarkan peserta didik untuk belajar dan memperoleh ilmu. Pembelajaran sejarah adalah bagaimana agar peserta didik mau belajar sejarah. Melalui pembelajaran sejarah, diharapkan peserta didik mampu memahami dam memaknai berbagai peristiwa sejarah. Tak hanya itu, pembelajaran sejarah memegang peranan yang sangat vital karena merupakan wahana pendidikan untuk mengenal diri dan bangsanya. Peran lainnya yakni sebagai landasan keterampilan intelektual dan sosial dari generasi muda penerus bangsa.

Pentingnya pendidikan sejarah dalam suatu kehidupan bangsa dan negara, karena bangsa yang besar adalah bangsa yang sangat menghargai sejarah bangsanya. Dalam pelaksanaan pembelajaran sejarah di sekolah, segala sesuatu yang ditinggalkan oleh sejarah untuk dijadikan pengalaman yang berharga belum betul - betul dimaknai oleh peserta didik.

Dalam pembelajaran sejarah kemampuan berpikir sejarah (historical thinking) diharapkan dapat membuat siswa menjadi aktif serta dapat meningkatkan hasil belajar siswa dan memudahkan siswa dalam memahami materi khususnya pada mata pelajaran sejarah. Melalui kemampuan berpikir historis mempersiapkan anak didik untuk mengembangkan kemampuan dalam menghadapi berbagai informasi yang sudah tersedia. Peserta didik akan lebih siap dalam upaya mengembangkan diri karena ia memiliki alat yang Sutjiatiningsih dan Sri $(2013 ; 5)$ megemukakan bahwa pembelajaran merupakan kegiatan untuk menghantarkan peserta didik untuk belajar dan memperoleh ilmu. Pembelajaran sejarah adalah bagaimana agar peserta didik mau belajar sejarah. Melalui pembelajaran sejarah, diharapkan peserta didik mampu memahami dam memaknai berbagai peristiwa sejarah. Tak hanya itu, pembelajaran sejarah memegang peranan yang sangat vital karena merupakan wahana pendidikan untuk mengenal diri dan bangsanya. Peran lainnya yakni sebagai landasan keterampilan intelektual dan sosial dari generasi muda penerus bangsa.

Berdasarkan hasil obeservasi awal di SMA N 2 Koto XI Tarusan Kabupaten Pesisir Selatan, peneliti menemukan bahwa dalam kegiatan pembelajaran sejarah terjadi kepasifan siswa dikelas, pembelajaran dilakukan dengan menggunakan metode ceramah dan siswa disuruh mencatat. Namun bagi siswa yang duduk dibagian belakang tidak memperhatikan guru dan bahkan tidak mencatat apa yang dijelaskan guru. Peerapan metode pembelajaran yang masih menggunakan metdoe konvensional sebagai metode utama selama proses pembelajaran, sehingga secara interaktif siswa belum dilibatkan secara aktif dalam pembelajaran.

Berdasarkan hasil obeservasi awal di SMA N 2 Koto XI Tarusan Kabupaten Pesisir Selatan Provinsi Sumatera Barat, peneliti menemukan bahwa dalam kegiatan pembelajaran sejarah terjadi kepasifan siswa dikelas, pembelajaran dilakukan dengan menggunakan metode ceramah dan siswa disuruh mencatat. Namun bagi siswa yang duduk dibagian belakang tidak memperhatikan guru dan bahkan tidak mencatat apa yang dijelaskan guru. Dengan demikian tidak terlihat adanya inovasi, dan keaktifan antara guru dan siswa, sehingga membuat pembelajaran sejarah ini menjadi pasif dan tidak berwarna. Dalam hal ini terlebih lagi selama mengikuti pelajaran ada beberapa siswa dalam keadaan ngantuk, main handphone dan mengobrol dengan siswa sebangkunya. Disisi lain permasalahan yang di hadapi guru sejarah adalah hasil belajar siswa yang rendah dibandingkan dengan ketetapan nilai pembelajaran di sekolah SMA N 2 Koto XI Tarusan, untuk mata pelajaran sejarah di sekolah ini adalah 7,5 pada tahun 2016/2017, dengan ketetapan tersebut masih banyak siswa yang belum mencapai Standar Kompetensi Lulusan (SKL) sejarah dan untuk memenuhi nilai SKL guru harus berusaha memperbaikinya dengan remedial.

Dalam mengatasi permasalahan tersebut maka lebih tepat guru menerapkan Metode pembelajaran cooperative script. 
Martinis Yamin (2013;8-9) membantu antara guru dan siswa hendaknya mengacu pada peningkatan aktivitas dan partisipasi siswa. Guru tidak hanya melakukan kegiatan penyampaian pengetahuan, keterampilan, dan sikap kepada siswa, akan tetapi guru diharapkan mampu membawa siswa untuk aktif dalam berbagai bentuk pembelajaran berupa penemuan, belajar mandiri, belajar kelompok, belajar memecahkan masalah, dan sebagainya. Hasil belajar siswa selain dipengaruhi oleh metode pembelajaran juga dipengaruhi oleh partisipasi siswa. Jika siswa aktif dan berpatisipasi dalam pembelajran, maka bukan hanya aspek prestasi saja yang akan diraih, namun ada aspek lain diperoleh yaitu aspek efektif dan aspek sosial.Kaitannya adalah

Menurut Lie (2013;9) merupakan sebuah paradigma lama dimana guru memberikan pengetahuan kepada siswa yang pasif sudah tidak bisa dipertahankan lagi. Untuk itu guru perlu menyusun dan melaksanakan kegiatan pembelajaran berdasarkan pokok pemikiran, yaitu: (1) pengetahuan ditemukan, dibentuk, dan dikembangkan oleh siswa, (2) siswa membangun pengetahuan secara aktif, (3) guru perlu mengembangkan kompetensi dan kemampuan siswa, (4) pendidikan adalah interaksi pribadi diantara para siswa dan interaksi antara guru dan siswa. Salah satu metode pembelajaran yang dapat mengatasi rendahnya partisipasi siswa adalah dengan metode pembelajaran kooperatif. Metode pebelajaran kooperatif menuntut semua anggota kelompok belajar dapat saling bertatap muka sehingga siswa dapat melakukan dialog tidak hanya dengan guru tetapi juga dengan siswa yang lain.

$$
\text { Menurut Yamin }
$$

pembelajaran konvensional mengutamakan daya ingat, siswa belajar secara individual, pembelajaran dikembangkan oleh guru, siswa penerima informasi secara pasif, mengupayakan siswa menerima materi yang disampaikan oleh guru (teacher centered), peyajian materi disajikan berdasarkan teoritis. Pembelajaran konvensional terlihat di dalamnya bahwa proses pembelajaran lebih banyak didominasi oleh guru dalam menyaring ilmu kepada siswa, sementara siswa lebih pasif sebagai informasi. Dalam penyampaian informasi, prinsip, teori dan ilmu pengetahuan lainnya dilakukan oleh guru secara lisan dan siswa yang menjadi pendengarnya.

Richard, L. Mumpford (2006;34-35), dalam artikelnya yang berjudul "Teaching History Through Analytical and Reflektif Thinking Skills", yang lebih menekankan perlunya pendekatan dalam proses pembelajaran yang mendorong siswa melakukan analisis atau berpikir kritis terhadap fakta-fakta tersebut.

Nana Supriatna dan Erlina Wiyanarti $(2008 ; 141)$ berpendapat bahwa pada pembelajaran sejarah pemahaman dalam membaca buku teks harus diikuti dengan strategi bertanya pertanyaan-pertanyaan dapat dilakukan menurut model Taxonomy Bloom melalui enam level pengetahuan selain yang harus dikuasai dalam pembelajaran sejarah, diperlukan pula kemampuan berpikir historis yang menurut Myers terdiri dari 4 kemampuan yaitu :1) Kemampuan belajar untuk mengevaluasi bukti-bukti sejarah., 2) Mengembangkan perbandingan berdasarkan argumenargumen Historis, 3) Interprestasi rekaman sejarah berdasarkan argumen-argumen Historis, 4) Memiliki perspektif atas dasar pemberian kesimpulan informasi yang bermanfaat bagi kehidupan masa kini.

Metode pembelajaran kooperatif yang bisa disarankan efektif adalah proses pembelajaran di kelas yang dapat membantu siswa aktif berbicara dan merujuk pada berbagai macam metode pembelajaran dimana para siswa diminta bekerja dalam kelompok - kelompok kecil untuk saling membantu satu sama yang lainnya dalam mempelajari sebuah materi pelajaran. Salah satu metode pembelajaran kooperatif yang dapat digunakan dalam proses pembelajaran sejarah adalah metode yang mampu meningkatkan daya ingat siswa yaitu metode pembelajaran kooperatif tipe Cooperatif Script. Peneliti akan menggunakan salah satu tipe metode pembelajaran cooperative script dalam penelitian ini dan membangkitkan pola pikir Historis terhadap siswa - siswi. 


\section{METODE}

Penelitian ini dirancang dengan menggunakan metode eksperimen. Dalam penggunaan metode ini menguji pengaruh metode pembelajaran coopertaive script dan kemampuan berpikir historis terhadap hasil belajar sejarah pada siswa SMA. Penelitian ini menggunakan desain treatment by level $2 \times 2$. Hipotesa yang diajukkan yakni: 1) Hasil belajar sejarah siswa yang diberikan metode pembelajaran cooperative script lebih tinggi dari siswa yang diberikan metode pembelajaran konvensional; 2) Terdapat pengaruh interaksi antara metode pembelajaran dengan kemampuan berpikir historis terhadap hasil belajar siswa; 3) Hasil belajar sejarah siswa yang diberikan metode pembelajaran cooperative script dengan memiliki kemampuan berpikir historis tinggi lebih tinggi dari siswa yang diberikan metode pembelajaran konvensional dengan memiliki kemampuan berpikir historis tinggi; 4) Hasil belajar sejarah siswa yang diberikan metode pembelajaran cooperative script dengan memiliki kemampuan berpikir historis rendah lebih rendah dari siswa yang diberikan metode pembelajaran konvensional dengan memiliki kemampuan berpikir historis rendah.

Penelitian ini menggunakan metode kuantitatif dengan jenis penelitian eksperimen dengan melibatkan tiga variabel. Dua variabel yang akan diteliti adalah pengaruh metode pembelajaran cooperative scrift (X1) dan kemampuan berpikir historis (X2) sebagai variabel bebas sedangkan variabel terikat (dependent variabel) adalah Hasil Belajar peserta didik (Y). Metode penelitian yang digunakan adalah metode eksperimen dengan rancangan faktorial $2 \mathrm{x}$ 2. Pola rancangan faktorial $2 \times 2$ adalah sebagai berikut :

Tabel 1. Rancangan Faktorial 2 x 2

\begin{tabular}{lll}
\hline Kemempuan Berpikir & \multicolumn{2}{l}{ Metode Pembelajaran $(\mathrm{A})$} \\
\cline { 2 - 3 } Historis $(\mathrm{B})$ & Cooperative Script $\left(\mathrm{A}_{1}\right)$ & Konvensional $\left(\mathrm{A}_{2}\right)$ \\
\hline Tinggi $\left(\mathrm{B}_{1}\right)$ & $\mathrm{A}_{1} \mathrm{~B}_{1}$ & $\mathrm{~A}_{2} \mathrm{~B}_{1}$ \\
\hline Rendah $\left(\mathrm{B}_{2}\right)$ & $\mathrm{A}_{1} \mathrm{~B}_{2}$ & $\mathrm{~A}_{2} \mathrm{~B}_{2}$ \\
\hline
\end{tabular}

Keterangan :

$\mathrm{A}_{1} \quad=$ Perlakuan metode pembelajaran cooperative script

$\mathrm{A}_{2} \quad=$ Perlakuan metode pembelajaran konvensional

$\mathrm{B}_{1} \quad=$ Kelompok siswa yang memiliki kemampuan berfikir historis tinggi

$\mathrm{B}_{2} \quad=$ Kelompok siswa yang memiliki kemampuan berfikir historis rendah

$\mathrm{A}_{1} \mathrm{~B}_{1} \quad=$ Kelompok siswa yang menggunakan metode pembelajaran cooperative script

dengan kemampuan berpikir historis tinggi

$\mathrm{A}_{1} \mathrm{~B}_{2} \quad=$ Kelompok siswa yang menggunakan metode pembelajaran cooperative script

dengan kemampuan berpikir historis rendah

$\mathrm{A}_{2} \mathrm{~B}_{1} \quad=$ Kelompok siswa yang menggunakan metode pembelajaran konvensional

dengan kemampuan berpikir historis tinggi

$\mathrm{A}_{2} \mathrm{~B}_{2} \quad=$ Kelompok siswa yang menggunakan metode pembelajarankonvensional dengan kemampuan berpikir historis rendah

Populasi target dalam penelitian adalah 766 siswa SMA N 2 Koto XI Tarusan Kabupaten Pesisir Selatan. Sedangkan populasi terjangkau adalah peserta didik kelas XI IPS SMA N 2 Koto XI Tarusan Kabupaten Pesisir Selatan. Sedangkan sampel dalam penelitian dilakukan dengan teknik random sampling. Sampel dalam penelitian ini yaitu kelas XI
IPS1 sebagai kelas eksperimen dan XI IPS2 sebagai kelas kontrol dangn masing-masing kelasnya berjumlah 30 siswa.

Kegiatan eksperimen dalam penelitian ini yaitu meliputi meliputi kelompok yang menggunakan metode cooperative script dan kelas kontrol kelompok yang menggunakan metode konvensional. Perlakuan yang 
digunakan dalam penelitian ini terdiri dari tiga aspek yaitu :

Materi dalam perlakuan ini adalah materi sejarah paham-paham baru dan kesadaran bangsa Indonesia dipelajari di SMA Negeri 2 Koto XI Tarusan Kabupaten Pesisir Selatan Tahun Pelajaran 2017/2018 semester Genap kelas XI yang mengacu pada kurikulum tingkat satuan pendidikan
(KTSP) dan di sesuaikan dengan pokok bahasan di semester genap.

Materi pembelajaran dan urutan penyajiannya diberikan sama pada kelompok perlakuan, perbedaannya pada metode yang digunakan dalam proses pembelajaran.

Rancangan Perlakuan

Perlakuan untuk kedua kelas tersebut seperti pada tabel 3.2 berikut ini :

Rancangan Perlakuan

\begin{tabular}{|c|c|c|}
\hline Kegiatan Pembelajaran & $\begin{array}{l}\text { Langkah-Langkah } \\
\text { Coopertive Script }\end{array}$ & $\begin{array}{l}\text { Langkah-Langkah Metode } \\
\text { Konvensional }\end{array}$ \\
\hline Kegiatan Pendahuluan & $\begin{array}{l}\text { 1. Guru menyampaikan tujuan } \\
\text { pembelajaran, tugas-tugas } \\
\text { yang harus dikerjakan } \\
\text { sehubungan dengan materi } \\
\text { tersebut dan membagi tugas } \\
\text { kelompok } \\
\text { 2. Guru menjelaskan tujuan dari } \\
\text { metode cooperative script }\end{array}$ & $\begin{array}{l}\text { 1. Guru menyampaikan tujuan } \\
\text { pembelajaran. } \\
\text { 2. Guru melakukan appersepsi } \\
\text { 3. Gurumenginformasikan } \\
\text { materi yang akan di bahas }\end{array}$ \\
\hline $\begin{array}{l}\text { Kegiatan Inti } \\
(30-35) \text { menit }\end{array}$ & $\begin{array}{l}\text { 1. Guru membagi siswa untuk } \\
\text { berpasangan } \\
\text { 2. Guru membagikan } \\
\text { wacana/materi tiap siswa } \\
\text { untuk dibaca dan membuat } \\
\text { ringkasannya. } \\
\text { 3. Guru dan siswa menetapkan } \\
\text { siapa yang pertama berperan } \\
\text { sebagai pembicara dan siapa } \\
\text { yang berperan sebagai } \\
\text { pendengar. } \\
\text { 4. Pembicara membacakan } \\
\text { ringkasannya selengkap } \\
\text { mungkin, dengan memasukkan } \\
\text { ide-ide pokok dalam } \\
\text { ringkasannya, sementara } \\
\text { pendengar menyimak } \\
\text { mengoreksi menunjukanide- } \\
\text { ide pokok yang kurang } \\
\text { lengkap dan memabantu } \\
\text { mengingat/menghafal ide-ide } \\
\text { pokok dengan } \\
\text { menghubungkan anarar materi } \\
\text { sebelumnya atau dengan } \\
\text { materi lainnya. } \\
\text { 5. Bertukar peran, semula } \\
\text { sebagai pembiacara ditukar } \\
\text { menjadi pendengar dan } \\
\text { sebaliknya. }\end{array}$ & $\begin{array}{l}\text { 1. Guru menjelaskan materi } \\
\text { dengan menggunakan } \\
\text { metode konvensional. } \\
\text { 2. Guru menjelaskan dan } \\
\text { meluruskan sejarah tentang } \\
\text { sejarah paham-paham baru } \\
\text { dan kesadaran bangsa } \\
\text { Indonesia. } \\
\text { 3. Siswa mengerjakan tugas } \\
\text { yang disiapkan guru pada } \\
\text { lembar kerja siswa. } \\
\text { 4. Guru memanggil siswa } \\
\text { secara acak untuk } \\
\text { mempresentasikan hasil } \\
\text { kerja mereka } \\
\text { 5. Guru memberikan } \\
\text { penguatan terhadap hasil } \\
\text { kerja siswa yang telah } \\
\text { dipresentasikan. } \\
\text { 6. Guru memberikan tes } \\
\text { berupa soal -soal pada } \\
\text { lembaran kuis. }\end{array}$ \\
\hline
\end{tabular}

Kegiatan Penutup

1. Refleksi

1. Refleksi 


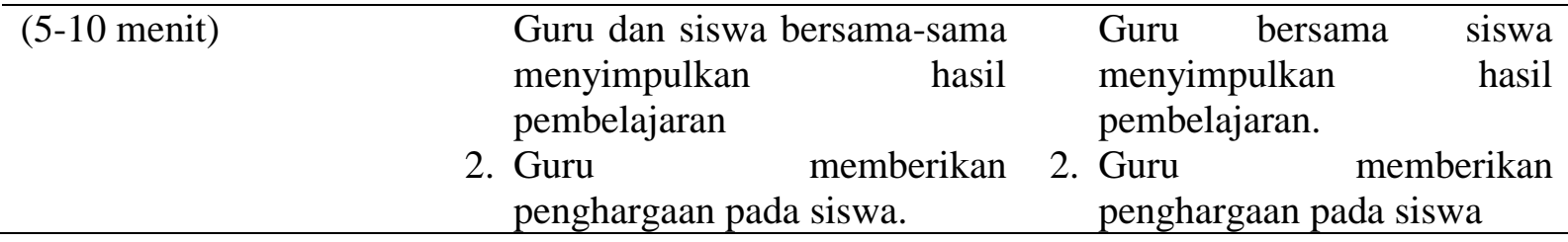

\section{HASIL DAN PEMBAHASAN}

\section{Hasil Penelitian}

Berdasarkan perhitungan ANAVA dua jalur ini dapat ditunjukan dari hasil analisis empiris pada pengujian $\mathrm{F}_{\text {hitung }}$ untuk metode pembelajaran sebesar 17,398 sedangkan $\mathrm{F}_{\text {tabel }}=4,20$ pada taraf nyatanya $\alpha=0,05$ karena nilai $F_{\text {hitung }}>F_{\text {tabel, }}$ maka (Ho) ditolak dan $\mathrm{H}_{1}$ diterima artinya dapat perbedaan hasil belajar sejarah antara siswa yang mengikuti metode pembelajaran cooperative script dan metode pembelajaran konvensional.

Berdasarkan hasil perhitungan ANAVA dapat diliha bahwa $F_{\text {hitung }}$ untuk faktor interaksi yaitu 73,746 lebih besar daripada $F_{\text {tabel }}$ yaitu 4,20 pada taraf nyata $\alpha=$ 0,05 . Hal ini menunjukkan bahwa terdapat pengaruh interaksi antara penggunaan metode pembelajaran dan kemampuan berpikir historis siswa terhadap hasil belajar siswa. Dari data tersebut maka disimpulkan Ho ditolak dan $\mathrm{H}_{1}$ diterima,

Dalam pengujian uji Tuckey dilakukan untuk membuktikan metode pembelajaran yang memberikan hasil belajar lebih baik melalui uji perbandingan antara kedua metode pembelajaran yang dipakai. Hasil uji Tuckey menunjukkan bahwa $\mathrm{Q}_{\text {hitung }}=12,76$ > $\mathrm{Q}_{\text {tabel }}=4,04$ pada taraf signifikansi 0,05. Berdasarkan hasil dalam pengujian hipotesis menggunakan kriteria pengujian $\mathrm{Ho}: \mu \mathrm{A}_{1} \mathrm{~B}_{1}$ $\leq \mu \mathrm{A}_{2} \mathrm{~B}_{1}$ ditolak dan $\mathrm{H}_{1}: \mu \mathrm{A}_{1} \mathrm{~B}_{1}>\mu \mathrm{A}_{2} \mathrm{~B}_{1}$ Diterima, dan skor rata-rata hasil belajar sejarah siswa yang diberikn metode pembelajaran cooperative script dengan memiliki kemampuan berpikir historis tinggi adalah 34,44 dan skor rata-rata hasil belajar sejarah siswa yang diberikan metode pembelajaran konvensional dengan memilik kemampuan berpikir historis tinggi adalah 25,78 .

Hasil uji Tuckey menunjukkan bahwa $\mathrm{Q}_{\text {hitung }}=4,42>\mathrm{Q}_{\text {tabel }}=4,04$ pada taraf signifikansi 0,05. Demikian dapat disimpulkan $\mathrm{H}_{0}$ ditolak dengan $\mathrm{H}_{1}$ diterima ${ }_{\mathrm{i}}$ hasil pengujian yang dilakukan membuktikan adanya perbedaan antara kelompok siswa yang diberikan metode pembelajaran coopertaive script dengan memiliki kemampuan berpikir historis rendah dan kelompok siswa yang diberikan dengan metode pembelajaran konvensional dengan memiliki kemampuan berpikir historis rendah.

\section{Pembahasan}

Berdasarkan pada deskripsi teoritis dan kerangka berpikir yang telah diajukan terdahulu, maka dapat diajukan hipotesis penelitian sebagai berikut :1) Hasil belajar sejarah siswa yang diberikan metode pembelajaran cooperative script lebih tinggi dari siswa yang diberikan metode pembelajaran konvensional, 2)Terdapat interaksi antara metode pembelajaran dengan kemampuan berpikir historis terhadap hasil belajar siswa pada materi sejarah Paham - Paham Baru, Kesadaran Bangsa Indonesia, dan Masa Pendudukan Jepang di Indonesia, 3)Hasil belajar sejarah siswa yang diberikan metode pembelajaran cooperative script dengan memiliki kemampuan berpikir historis tinggi lebih tinggi dan siswa yang diberikan metode pembelajaran konvensional dengan memiliki kemampuan berpikir historis tinggi, 4) Hasil belajar sejarah siswa yang diberikan metode pembelajaran cooperative dengan memiliki kemampuan berpikir historis rendah dari siswa yang diberikan metode pembelajaran konvensional dengan kemampuan berpikir historis rendah.

Hasil uji hipotesis pertama menolak $\mathrm{H}_{\mathrm{o}}$ dan menerima $\mathrm{H}_{1}$ hal ini membuktikan bahwa terdapat perbedaan hasil belajar sejarah antara siswa yang diberikan metode pembelajaran cooperative script dan siswa yang diberikan metode pembelajaran 
konvensional. Secara keseluruhan hasil belajar sejarah siswa yang diberikan metode pembelajaran cooperative script lebih tinggi dari siswa yang mengikuti metode pembelajaran konvesional. Metode pembelajaran cooperative script menekankan siswa untuk lebih aktif dalam pembelajaran dan dituntut untuk mencari jawaban dari masalah atau hipotetsis yang disusun dan memahami materi pelajaran sejarah yang diberikan oleh guru.

Hasil uji hipotesa kedua menolak $\mathrm{H}_{\mathrm{o}}$ dan menerima $\mathrm{H}_{1}$ hal ini menunjukkan bahwa terdapat pengaruh interaksi antara metode pembelajaran dan kemampuan berpikir historis terhadap hasil belajar sejarah siswa.

Siswa yang memilki kemampuan berpikir hsitoris tinggi cenderung lebih menyukai metode pembalajaran cooperative script karena matode pembelajaran cooperative script adalah kegiatan pembelajran yang lebih menekankan pada proses berpikir secara sistematis, logis, kristis, dan analistis atau mengembangkan kemampuan intelektual sebagai bagiandari proses mental. Sehingga siswa tidak hanya dituntut untuk menguasai materi pelajaran akan tetapi bagaimana siswa dapat mengembangkan potensi dirinya untuk mencari dan menemukan sendiri jawaban dari suatu masalah dengan cara melakukan penelitian dalam bentuk kelompok, mulai dari mengakaji buku-buku sejarah, berkunjung ke museum dan arsip daerah, disini akan terlihat sikap seorang siswa dapat memahami makna dari kemampuan berpikir historis. Siswa yang memiliki kemampuan berpikir rendah dia cenderung pasif, lebih suka menerima informasi dari guru tanpa mencari tahu sendiri dan cenderung bersikap berpuas diri dengan apa yang sudah diketahui.

Dari hasil pengujian hipotesis ketiga menolak $\mathrm{H}_{0}$ dan menerima $\mathrm{H}_{1} \mathrm{Hal}$ ini berarti bahwa hasil belajar sejarah siswa diberikan metode pembelajaran cooperative script dengan memiliki kemampuan berpikir historis tinggi dari siswa yang diberikan metode pembelajaran konvesional dengan memiliki kemampuan berpikir hsitoris tinggi. Proses pelaksanaan metode cooperative script memberikan kesempatan kepada siswa untuk aktif dalm melakuakn penelitian dan mencari bukti-bukti sejarah yang berkaitan dengan masalah tapi juga memungkinkan untuk mendapatkan informasi-informasi baru. Siswa dengan kemapuan berpikir historis tinggi dan mengikuti metode cooperative script lebih mudah memahami materi yang telah diberikan oleh guru dan aktif dalam pembelajaran.

Hasil pengujian hipotesis keempat menolak $\mathrm{H}_{0}$ dan menerima $\mathrm{H}_{1}$ hal ini berarti hasil belajar sejarah siswa yang diberikan metode pembelajaran cooperative script dengan memiliki kemampuan berpikir historis rendah dari siswa yang diberikan metode pembelajaran konvensional dengan memiliki kemampuan berpikir historis rendah. Hal ini dimungkinkan karena metode pembelajaran cooperative script menuntut siswa untuk lebih aktif, saling berinteraksi dan berusaha mencari sendiri pemecahan masalah yang diberikan oleh guru sehingga membuat siswa yang memiliki kemampuan berpikir historis rendah merasa terbebani dengan tugas yang harus dikerjakan.

Metode konvensional pada umumnya cenderung disukai oleh siswa yang memilki kemampuan berpikir historis rendah karena metode ini cenderung berpusat pada guru, informasi materi pembelajarannya banyak yang didapatkan dari guru dan didalam proses pembelajaran berlangsung siswa hanya sekedar mendengarkan dan mencatat apa yang disampaikan guru. Sehingga hasil belajar sejarah siswa yang diberikan metode pembelajaran cooperative script dengan memiliki kemampuan berpikir historis rendah lebih rendah dari siswa yang diberikan metode pembelajaran konvensional dengan memiliki kemampuan berpikir historis rendah.

\section{SIMPULAN DAN SARAN}

Secara umum terdapat perbedaan hasil belajar sejarah antara siswa yang diberikan metode pembelajaran cooperative script dengan siswa yang diberikan metode pembelajaran konvensional. Pembelajaran 
dengan menggunakan metode cooperative script sebaiknya diberikan kepada siswa kelas XI IPS SMA N 2 Koto XI Tarusan Kabupaten Pesisir Selatan Provinsi Sumatera Barat.Interaksi yang ditunjukkan antara metode pembelajaran dan kemampuan berpikir historis terhadap hasil belajar sejarah dapat dijadikan dasar dalam memilih metode pembelajaran yang efektif dengan memperhatikan kemampuan berpikir historis siswa.Hasil belajar sejarah siswa yang diberikan metode pembelajaran cooperative script dengan memiliki kemampuan berpikir historis tinggi lebih tinggi dari siswa yang diberikan metode pembelajaran konvensional dengan memiliki kemampuan berpikir historis tinggi.

Hal ini berarti metode pembelajaran cooperative script sebaiknya diberikan kepada siswa yang memiliki kemampuan berpikir historis tinggi.Hasil belajar sejarah siswa yang diberikan metode pembelajaran cooperative script dengan memilki kemampuan berpikir historis rendah lebih rendah dari siswa yang diberikan metode pembelajaran konvensional dengan memiliki kemampuan berpikir historis rendah. Hal ini berarti metode pembelajaran konvensionalsebaiknya diberikan kepada siswa yang memiliki kemampuan berpikir historis rendah. Oleh karena itu pelaksanaan metode pembelajaran ini perlu perhatian dari pihak guru maupun sekolah. Bagi guru sejarah, metode pembelajaran ini dapat membantu guru dalam hal menyajikan materi kepada siswa sehingga siswa lebih siap dan matang dalam merima materi pelajaran baik secara indiviu maupun itu berbentuk suatu kelompok pembelajaran.

\section{DAFTAR PUSTAKA.}

Abdurahman, Mulyono. Pendidikan Bagi Anak Berkesulitan Belajar. Jakarta : Rineka Cipta, 2003

Agus Suprijono, Cooperative Leraning. Yogyakarta: Pustaka Pelajar, 2009.

Arukunto, Suharsimi, Dasar - Dasar Evaluasi Pendidikan. Jakarta : Bumi Aksara, 2001.
Akbar, Purnomo Setiady dan Husaini Usman. 2006. Pengantar Statistika Edisi Kedua. Jakarta : PT Bumi Aksara Akdon dan Riduwan .2013. Rumus dan Data dalam Analisis Statistika. Bandung: Alfabeta.

Departemen Pendidikan Nasional. Peraturan Menteri Pendidikan Nasional No. 22 Standar Isi Kurikulum Tingkat Satuan Pendidikan, Jakarta : Depdiknas, 2006.

Dirnyati dan Mudijono. Belajar dan Pemebelajaran. Jakarta Rineka Cipta.2006

Eveline Siregar dan hartini Nara. Teori Belajar dan Pembelejaran, Jakarta : Ghalia Indonesia, 2010

Gottschalk, Louis, Mengerti Sejarah. Jakarta : Universitas Indonesia, 2006.

Hamalik, Oemar. Perencanaan Pengajaran berdasarkan Pendekatan Sitem. Jakarta : Bumi Aksara, 2001

Hariyono, Mempelajari Sejarah secara efektif.(Malang:Pustaka Jaya, 2012

Isjoni, Pembelajaran Kooperatif. Yogyakarta : Pustaka Belajar, 2009..,

Kuntowijoyo. Pegantar Ilmu Sejarah. Yogyakarta : Bentang Budaya, 2001.

Lie, Anita, Cooperative Learning : Mempraktikan Cooperative Leraning diRuang - Ruang Kelas. Jakarta : Grasindo, 2010.

Mulyasa, E. Standar Kompetensi dan Sertifikasi Guru. Bandung : Rosda Karya. 2008.

Nana Supriatna dan Erlina Wiyanarti (ed), Sejarah dalam Keberagaman, (Bandung: UPI, 2008. 
Robert E, Slavin, Cooperative Learning : Teori, Riset dan Praktik. Bandung: Nusa Madia, 2008.,

Orianto dan Wahidin. Model Penilaian Kemamouan Berpikir Historis (Historical Thinking) Dengan Model Rasch. Jurnal Pendidikan Sejarah Fakultas Ilmu Sosial Universitas Negeri Padang Volume. XI. No. 1, 14-16

Jurnl,Sejarah.unp.ac.id?index.php/fis /article/view/45/85 (Diakses 22 November 2017).

Sanjaya, Wina. Strategi Pembelajaran Berorientasi Standar Proses Pendidikan. Jakarta : KencanaPrenada Media Grup, 2002.

S.K. Kochhar. History of Teaching. Jakarta: Grasindo, 2008

Slameto. Belajar dan Faktor - Faktor yang Mempengaruhinya. Jakarta; Rineka Cipta, 2003.

Slameto. Evaluasi Pendidikan. Jakarta : Bumi Aksara, 2003

Slavin, Robert E. Cooperative Learning : Teori, Riset, dan Praktik. Bandung : Penerbit Nusa Media, 2008

Sudjana. Metode Statitika. Bandung. Tarsito. 2016

Sudjana, Nana. Penilaian Hasil Proses Belajar Mengajar. Bandung : Rosda Karya, 2002.

Sudjono, Anas. Pengantar Statistika Pendidikan. Jakarta ; Grafindo Persada, 2006.
Supratinya dan Kristiyani. Efektifitas Metode Problem - Based Learning dalam Pembelajaran Mata Kuliah Teori Psikologi Kepribadian II, Jurnal Psikologi Fakultas Psikologi Universitas Gadjah Mada Volume 33, No. 1, $17 \quad-\quad 32$, Jurnl.psikologi.ugm.ac.id?index.php / fpsi/article/view/81/71 (Diakses 16 November 2017).

Supriatna, Nana, dan Erlina Wiyanarti . Sejarah Dalam Keberagaman. Bandung. UPI. 2008

Supriatna, Nana, Konstruksi Pemelajaran Sejarah Kritis. Bandung Historia Utama Press. 2007

Supriyono, Agus, Cooperative Learning : Teori \& Aplikasi PAIKEM. Yogyakarta : Pustaka Pelajar, 2009.

Wina Sanjaya, Strategi Pembelajaran Berorientasi Standar Proses Pendidikan. Jakarta: Kencana Penada Media Grup, 2002

Wingkel w.s. Psikologi Pendidikan. Yogyakarta : Media Abadi, 2005.

Winneburg Sham. Berfikir Historis. Jakarta : Yayasan Obor Indonesia. 2006.

W. John. Santrock. Psikologi Pendidikan. Jakarta : Pranada Meida Grup, 2007.

zMuhammad Kholik. Metode Konvensional. http: // muhammadkholik. Wordpress .com /2011/11/08 metodepembelajaran-konvensional/ (diakses 16 November 2017). 